\title{
New species and records of Pyxine (Caliciaceae) in China
}

\author{
Mei-Xia Yang ${ }^{1,2,3}$, Xin-Yu Wang ${ }^{3}$, Dong Liu', ${ }^{3,4}$, Yan-Yun Zhang ${ }^{3}$, Li-Juan Li ${ }^{3}$, \\ An-Cheng Yin ${ }^{3}$, Christoph Scheidegger ${ }^{1,2}$, Li-Song Wang ${ }^{3}$ \\ I Swiss Federal Institute for Forest, Snow and Landscape Research (WSL), Zürcherstrasse 111, CH-8903 \\ Birmensdorf, Zurich, Switzerland 2 University of Bern, Hochschulstrasse 6, 3012 Bern, Switzerland 3 Key \\ Laboratory for Plant Diversity and Biogeography of East Asia, Kunming Institute of Botany, Chinese Academy \\ of Sciences, Heilongtan, Kunming, Yunnan 650201, China 4 Korean Lichen Research Institute (KoLRI), Sun- \\ chon National University, 255 Jungang-Ro, Suncheon, Korea
}

Corresponding author: Li-Song Wang (wanglisong@mail.kib.ac.cn)

Academic editor: G. Rambold | Received 20 September 2018 | Accepted 10 December 2018 | Published 29 January 2019

Citation: Yang M-X, Wang X-Y, Liu D, Zhang Y-Y, Li L-J, Yin A-C, Scheidegger C, Wang L-S (2019) New species and records of Pyxine (Caliciaceae) in China. MycoKeys 45: 93-109. https://doi.org/10.3897/mycokeys.45.29374

\begin{abstract}
In this study, the diversity of Pyxine Fr. in China was assessed based on morphological and chemical traits and molecular data are inferred from ITS and mtSSU sequences. Nineteen species were recognised, including three that are new to science (i.e. P. flavicans M. X. Yang \& Li S. Wang, P. hengduanensis M. X. Yang \& Li S. Wang and P. yunnanensis M. X. Yang \& Li S. Wang) and three records new to China were found (i.e. P. $\operatorname{cog}$ nata Stirt., P. himalayensis Awas. and P. minuta Vain.). Pyxine yunnanensis is diagnosed by the small size of the apothecia, a white medulla of the stipe and the presence of lichexanthone. Pyxine flavicans is characterised by broad lobes, a pale yellow medulla of the stipe and the presence of atranorin. Pyxine hengduanensis can be distinguished by its pale yellow medulla, marginal labriform soralia and the absence of atranorin. Detailed descriptions of each new species are presented, along with a key to the known species of Pyxine in China.
\end{abstract}

\section{Keywords}

China, lichenised fungi, new species, phylogeny

Copyright Mei-Xia Yang et al. This is an open access article distributed under the terms of the Creative Commons Attribution License (CC BY 4.0), which permits unrestricted use, distribution, and reproduction in any medium, provided the original author and source are credited. 


\section{Introduction}

The lichen genus Pyxine was first established by Fries (1825). Molecular data support the placement of Pyxine in a clade of taxa that were previously placed in Physciaceae and the circumscription of the family has thus changed to Caliciacese (Wedin and Grube 2002; Crespo et al. 2004; Gaya et al. 2012; Prieto and Wedin 2017). Pyxine is characterised by an adnate foliose thallus, an internal stipe colour of apothecia, dark brown hypothecium and generally two-celled brown ascospores (Awasthi 1982; Elix 2009; Kalb 1987; Kalb 2004). The genus Pyxine consists of approximately 70 species. Most species are pantropical to subtropical and a few species extend into temperate or oceanic regions (Elix 2009; Mongkolsuk et al. 2012; Kalb 1987; Moberg 1983; Wei and Hur 2007).

Regional studies on this genus have been carried out in Australia (Elix 2009), Brazil (Aptroot et al. 2014), India (Awasthi 1982; Nayaka et al. 2013), Thailand (Mongkolsuk et al. 2012) and North and Central America (Imshaug 1957; Jungbluth and Marcelli 2011). Prior to this study, 13 species have been reported in China, including Pyxine berteriana, $P$. cocoes, $P$. consocians, $P$. copelandii, $P$. coralligera, $P$. endochrysina, P. limbulata, P. meissnerina, P. microspora, P. petricola, P. philippina, P. sorediata and $P$. subcinerea (Hu and Chen 2003; Obermayer and Kalb 2010; Wei 1991).

Although many studies have been conducted, few molecular phylogenetic analyses have been completed (Gaya et al. 2012; Schmull et al. 2011; Prieto and Wedin 2017). In this study, morphological, chemical and molecular phylogenetic analyses were combined in order to re-evaluate the species composition and phylogenetic relationship of this genus in China. In our study, 31 sequences were newly generated from freshly collected specimens.

\section{Methods}

\section{Morphological and chemical analyses}

The specimens examined in this study were collected from the Hengduan Mountains region, Taiwan, Zhejiang, Hainan et al. from 1941 to 2016 and deposited in KUN-L (325 specimens) and in the Institute of Microbiology (HMAS-L, 5). Morphological characteristics were studied using a dissecting microscope (Nikon SMZ745T) and a light microscope (Nikon Eclipse Ci-S; Nikon Instruments, Tokyo Japan). Sections were made with a razor blade under a dissecting microscope and anatomical characteristics were examined and measured using a micrometer under light microscopy. Ten measurements each of the thallus, apothecia and ascospore dimensions were taken from a single apothecium per specimen and the ranges of these measurements, from smallest to largest, are presented in this study. The lichen secondary metabolites were analysed using spot reactions and thin-layer chromatography in a solvent C system, according to Orange et al. (2001). 


\section{DNA extraction and sequencing}

Total genomic DNA was extracted from dried herbarium specimens using AxyPrep Multisource Genomic DNA Miniprep Kit 50-prep (Qiagen) according to the manufacturer's instructions. ITS (nrDNA ITS1-5.8S-ITS2) and mtSSU (mitochondrial small subunit $\mathrm{rDNA}$ ) were amplified by polymerase chain reactions (PCR) using the primer pairs ITS1F (Gardes and Bruns 1993), ITS4 (White et al. 1990) and mtSSU1/ mtSSU2R (Zoller et al. 1999).

Amplifications were performed in a $25 \mu \mathrm{l}$ volume comprising $12.5 \mu \mathrm{l}$ of $2 \times$ MasterMix (TapDNA Polymerase, 0.1 units/ $\mu$; technologies Co. Ltd), $1.0 \mu \mathrm{l}$ of

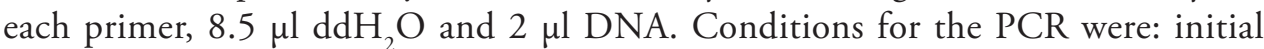
denaturation at $94^{\circ} \mathrm{C}$ for $4 \mathrm{~min}, 34$ cycles at $94^{\circ} \mathrm{C}$ for $1 \mathrm{~min}, 54^{\circ} \mathrm{C}$ for $1 \mathrm{~min}$ and $72{ }^{\circ} \mathrm{C}$ for $1.5 \mathrm{~min}$, with a final extension at $72{ }^{\circ} \mathrm{C}$ for $10 \mathrm{~min}$. PCR products were sequenced in an $\mathrm{ABI} 3730 \mathrm{X}$ using amplification primers manufactured by Tsingke (Kunming, China).

ITS and mtSSU sequences were assembled with Seqman 7.0 (DNAStar) and manually edited using Mega6. DNA sequences were aligned with MAFFT version 7 with default parameters (Katoh et al. 2005) via the online resource (http://mafft.cbrc.jp/ alignment/server/index.html).

\section{Phylogenetic analyses}

Maximum likelihood (ML) and Bayesian inference (BI) were conducted based on the two gene fragments combining ITS and mtSSU. The best-fitting substitution model was determined using MrModeltest 2.3 (Nylander 2005) and PAUP*4b10 (Swofford 2003), where the AIC values were calculated using JModelTest 3.7 (Posada 2008). ML analyses were performed using RAxML7.0.4 (Stamatakis 2006) with default settings (GTR) and support values were inferred from the $70 \%$ majorityrule tree based on 1000 non-parametric bootstrap pseudo-replicates. The Bayesian analyses were performed using MrBayes v3.1.2 (Huelsenbeck and Ronquist 2001) with 2,000,000 generations and four incrementally heated chains. MCMC (Markov Chain Monte Carlo) analysis started from a random tree that was sampled every $1000^{\text {th }}$ generation, with the first $10 \%$ of trees discarded as burn-in. A majorityrule consensus tree was constructed from the remaining trees to estimate posterior probability (PP), with values greater than or equal to 0.95 considered indicative of strong support. Tracer v1.6 (Rambaut and Drummond 2003) was used to ensure that stationarity was achieved by checking whether the log-likelihood values of sample points reached a stable equilibrium. Phylogenetic trees were visualised using the programme FigTree 1.4.0 (Rambaut 2012). Physcia dubia and Dirinaria applanata were selected as outgroups. 


\section{Results}

Nineteen species were recognised, including three that are new to science (i.e. Pyxine flavicans M. X. Yang \& Li S. Wang, P. hengduanensis M. X. Yang \& Li S. Wang and P. yunnanensis $\mathrm{M}$. X. Yang \& Li S. Wang) and three records new to China were found (i.e. P. cognata Stirt., P. himalayensis Awas. and P. minuta Vain.). Of the 39 sequences that were included in the phylogenetic analyses, 31 were newly generated (Table 1). A phylogenetic analysis using ITS and mtSSU sequences revealed 15 species. We were unable to obtain sequences from $P$. copelandii, $P$. coralligera, $P$. microspora and $P$. philippina, but the Chinese specimens agreed morphologically and chemically with the current circumscription of these species (Hu and Chen 2003; Obermayer and Kalb 2010; Wei 1991).

The ITS and mtSSU datasets were analysed separately and concatenated; both parsimony and Bayesian trees of ITS vs. mtSSU were congruent. A maximum likelihood phylogenetic tree was inferred from the combined dataset of ITS and mtSSU (Fig. 1). The monophyly of each species and the phylogenetic relationships between species were well supported (Fig. 1; MLBS > 90\%, PP > 0.95). Specifically, the three new species were all monophyletic with a high support value: Pyxine yunnanensis $(\mathrm{MLBS}=97 \%, \mathrm{PP}=1.00)$, P. flavicans $(\mathrm{MLBS}=99 \%, \mathrm{PP}=0.99)$ and $P$. hengduanensis (MLBS $=98 \%, \mathrm{PP}=1.00)$.

Species of Pyxine were separated into two main clades, as inferred from the phylogenetic tree with strong support (Fig. 1). The ten species in Clade 1 are all characterised by the presence of soralia or isidia on the thallus, whereas the five species in Clade 2 contain lichexanthone and lack soralia and isidia. The two species $P$. petricola and $P$. cocoes are characterised by the presence of both lichexanthone and soralia.

\section{Taxonomic treatment}

Nineteen Pyxine species were confirmed in China, including three species new to science and three species hereby newly reported for the country, based on the following characteristics: presence of isidia and soredia, colour of the medulla, main compounds, reaction of $\mathrm{K}$ on the internal stipe of apothecia, nature of the substrate and colour of the thallus.

\section{New species}

\section{Pyxine flavicans M. X. Yang \& Li S. Wang, sp. nov.}

MycoBank No.: MB819956

Figure 2

Holotype. CHINA, YUNNAN PROVINCE, Nujiang Perf., Chide Vil., $1916 \mathrm{~m}$ el-

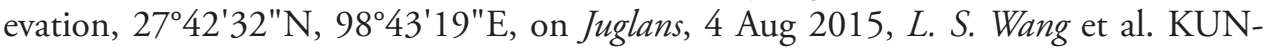
L15-48196. GenBank accession No.: ITS = KY611884, mtSSU = KY751391. 
Table I. Specimen information and GenBank accession numbers for taxa used in this study. Newly obtained sequences are shown in bold.

\begin{tabular}{|c|c|c|c|c|}
\hline \multirow{2}{*}{ Taxa } & \multirow{2}{*}{ Locality } & \multirow{2}{*}{ Voucher specimens } & \multicolumn{2}{|c|}{ Accession Number } \\
\hline & & & ITS & $\mathrm{mtSSU}$ \\
\hline Pyxine sorediata 1 & China: Yunnan & KUN 12-36993 & KY611891 & KY751398 \\
\hline P. sorediata 2 & China: Yunnan & KUN 15-48546 & KY611892 & KY751399 \\
\hline P. sorediata 3 & Sweden & Wetmore 91254 & JX000111 & $\begin{array}{c}- \\
\text { KX512973 }\end{array}$ \\
\hline P. hengduanensis 1 & China: Yunnan & KUN 15-48082 & KY611889 & KY751396 \\
\hline P. hengduanensis 2 & China: Yunnan & KUN14-43258 & KY611890 & KY751397 \\
\hline P. endochrysina 1 & China: Xizang & KUN 14-46462 & KY611887 & KY751394 \\
\hline P. endochrysina 2 & China: Xizang & KUN 14-46439 & KY611888 & KY751395 \\
\hline P. limbulata 1 & China: Taiwan & KUN 15-49117 & KY611885 & KY751392 \\
\hline P. limbulata 2 & China: Taiwan & KUN 15-49153 & KY611886 & KY751393 \\
\hline P. himalayensis 1 & China: Yunnan & KUN 12-36055 & KY611881 & KY751388 \\
\hline P. himalayensis 2 & China: Xizang & KUN 14-46410 & KY611882 & KY751389 \\
\hline P. flavicans 1 & China: Yunnan & KUN 14-43995 & KY611883 & KY751390 \\
\hline P. flavicans 2 & China: Yunnan & KUN 15-48196 & KY611884 & KY751391 \\
\hline P. meissnerina 1 & China: Yunnan & KUN 12-34386 & KY611877 & KY751384 \\
\hline P. meissnerina 2 & China: Yunnan & KUN 12-34377 & KY611878 & KY751385 \\
\hline P. consocians 1 & China: Yunnan & KUN 15-49942 & KY611879 & KY751386 \\
\hline P. consocians 2 & China: Yunnan & KUN 15-47417 & KY611880 & KY751387 \\
\hline P. petricola 1 & China: Yunnan & KUN 13-40715 & KY611875 & KY751382 \\
\hline P. petricola 2 & China: Sichuan & KUN 13-39419 & KY611876 & KY751383 \\
\hline P. cocoes 1 & China: Taiwan & KUN 15-49457 & KY611874 & KY751381 \\
\hline P. minuta 1 & China: Yunnan & KUN 13-40695 & KY611872 & KY751379 \\
\hline P. minuta 2 & China: Yunnan & KUN 13-40630 & KY611873 & KY751380 \\
\hline P. yunnanensis 1 & China: Yunnan & KUN 13-41372 & KY611870 & KY751377 \\
\hline P. yunnanensis 2 & China: Yunnan & KUN 13-40596 & KY611871 & KY751378 \\
\hline P. berteriana 1 & China: Yunnan & KUN 15-47921 & KY611868 & KY751375 \\
\hline P. berteriana 2 & China: Yunnan & KUN 14-43730 & KY611869 & KY751376 \\
\hline P. subcinerea 1 & China: Taiwan & KUN 15-48998 & KY611866 & KY751373 \\
\hline P. subcinerea 2 & China: Taiwan & KUN 15-49012 & KY611867 & KY751374 \\
\hline P subcineres & USA & NC 27708 & HQ650705 & - \\
\hline 1. subctnerea & Spain & MAF9852 & - & AY464080 \\
\hline P. cognata 1 & China: Yunnan & KUN 14-43569 & KY611864 & KY751371 \\
\hline P. cognata 2 & China: Yunnan & KUN 13-40767 & KY611865 & KY751372 \\
\hline $\begin{array}{l}\text { P. berteriana var. } \\
\text { himalaica } 1\end{array}$ & China: Yunnan & KUN 14-43571 & KY611862 & KY751369 \\
\hline $\begin{array}{l}\text { P.berteriana var. } \\
\text { himalaica } 2\end{array}$ & China: Yunnan & KUN 13-40706 & KY611863 & KY751370 \\
\hline Dirinaria & India & - & EU722342 & - \\
\hline applanata & Spain & MAF 9854 & - & AY464079 \\
\hline Physcia dubia & Finland & T. Ahti 69359 & $\begin{array}{c}\text { JQ301695 } \\
-\end{array}$ & $\begin{array}{c}- \\
\text { JQ301536 }\end{array}$ \\
\hline
\end{tabular}

Description. Thallus 5-9 cm wide, attached to closely adnate. Lobes radiating, plane to convex, but often slightly concave towards the tips, (0.5) 1-3 (4) mm wide, subround at the apices. Upper surface white-grey to celadon, sparsely pruinose at the lobe tips or epruinose, isidia and soredia absent. Medulla pale yellow above, white below. Lower surface black in the centre, paler towards the margin; rhizines dense, 


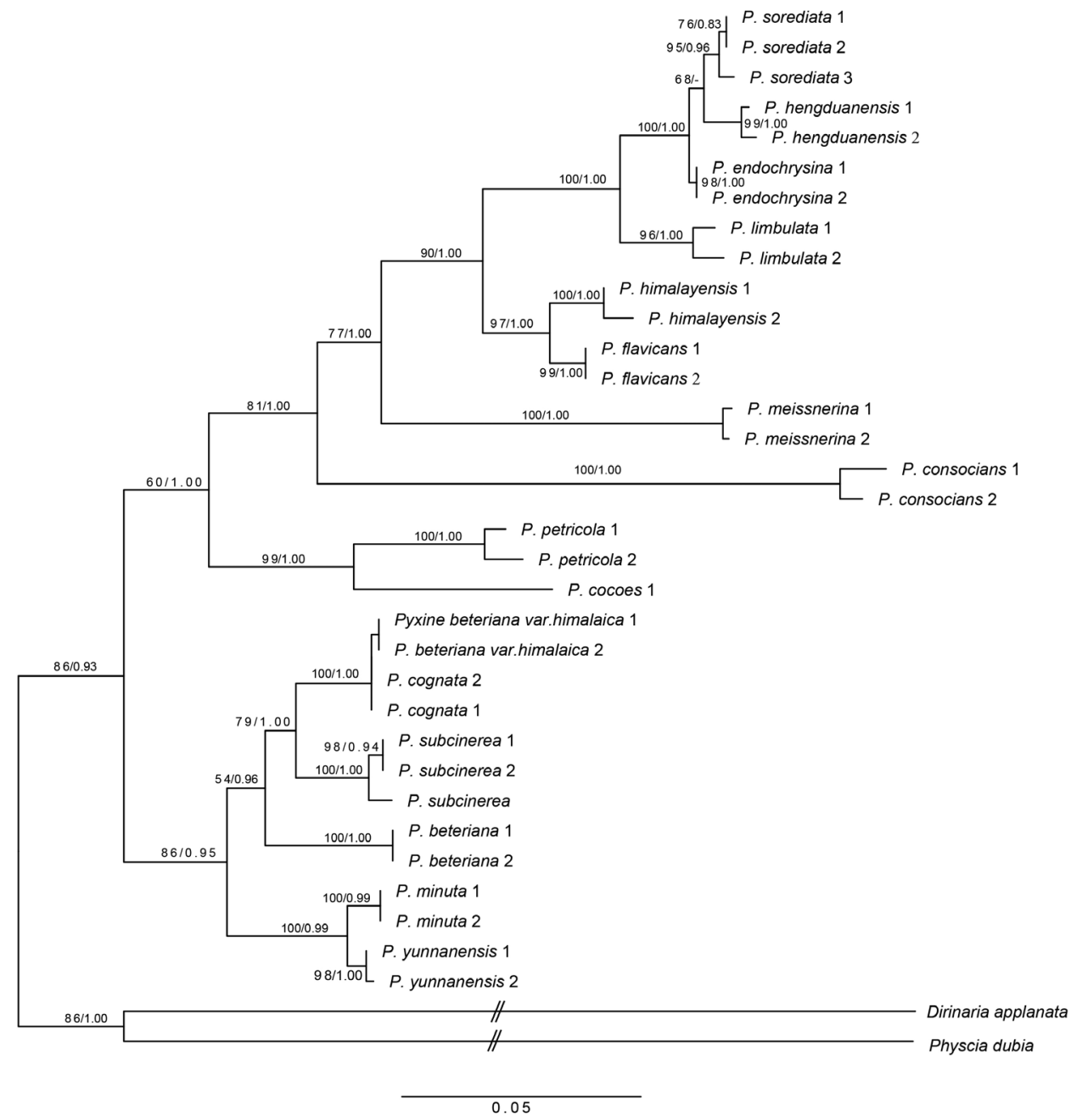

Figure I. Phylogenetic relationship of Pyxine species occurring in China inferred from ITS and $\mathrm{mtSSU}$ sequences using maximum likelihood (values refer to ML bootstrap frequencies and Bayesian posterior probabilities).

furcate. Apothecia common, (0.5) 0.8-1.5 (2) mm wide, constricted at base, plane to possibly convex; margin black. Hymenium height $80-120 \mu \mathrm{m}$; hypothecium light brown to brown, internal stipe $\mathrm{K}$ - pale yellow to yellow; spores brown, two-celled, 18-20 × 6-8 $\mu \mathrm{m}$. Upper cortex K+ yellowish, UV-; medulla K-, C-; containing atranorin, chloroatranorin (minor), zeorin and unknown terpenes.

Habitat and distribution. Growing on bark of Quercus and Picea spp. and on rocks around 1916-4000 m elevation in semi-arid environments; only known from south-western China.

Etymology. The epithet flavicans refers to the yellow medulla and internal stipe of the apothecia. 

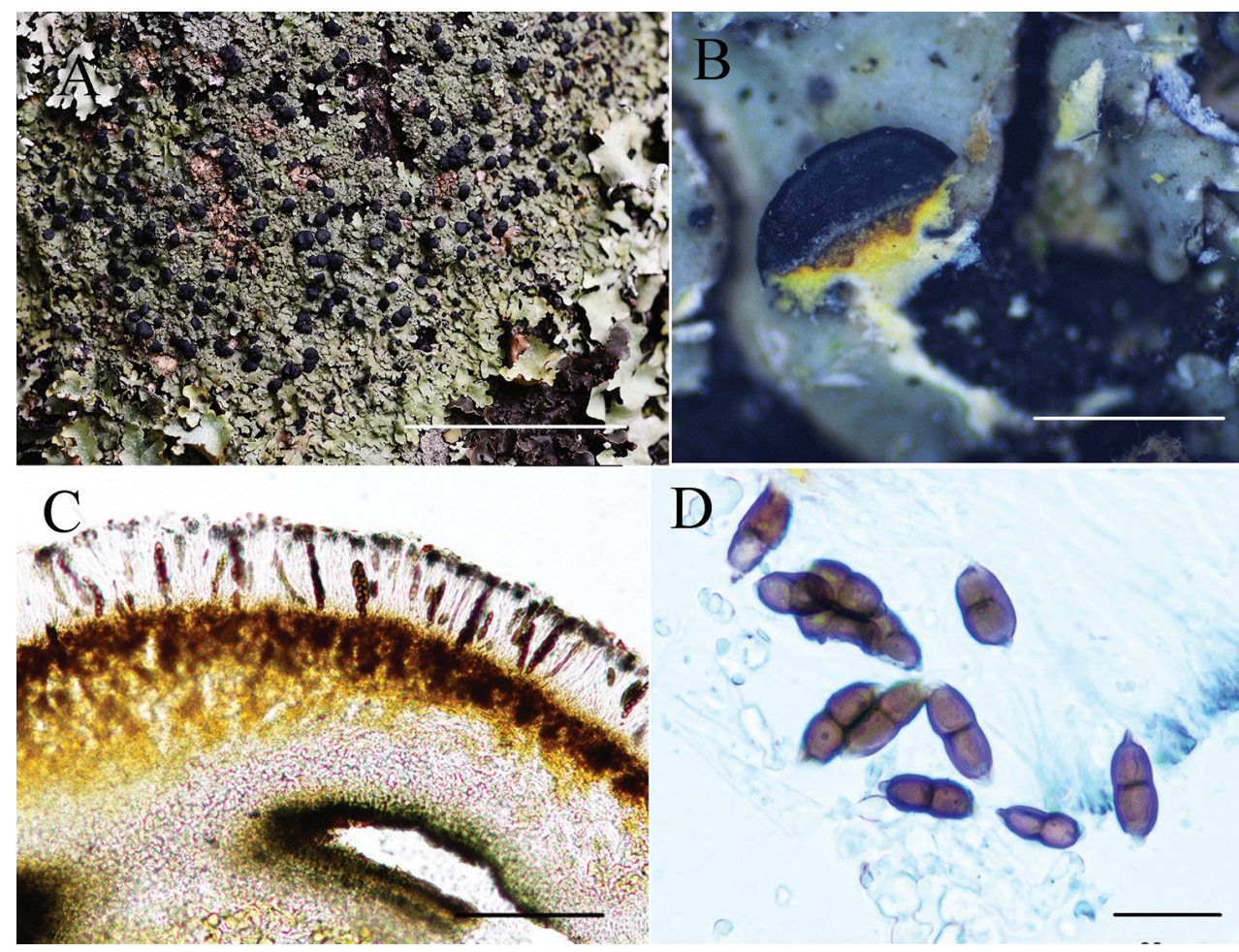

Figure 2. Pyxine flavicans (KUN-L 15-48196) photographed by Li-Song Wang and Meixia Yang. A habit $\mathbf{B}$ yellow internal stipe of apothecia $\mathbf{C}$ hymenium $\mathbf{D}$ ascospores from GAW (glycerine:alcohol:w ater=1:1:1). Scale bars: $5 \mathrm{~cm}(\mathbf{A}) ; 0.5 \mathrm{~cm}(\mathbf{B}) ; 100 \mu \mathrm{m}(\mathbf{C}) ; 20 \mu \mathrm{m}(\mathbf{D})$.

Notes. Pyxine flavicans is characterised by flat corticated yellowish-grey to brownish-grey thalli, a constricted base, a pale yellow medulla and the presence of atranorin.

This species resembles $P$. berteriana in terms of lobe size, saxicolous habitat and internal stipe, but the latter has a yellow to yellowish-orange medulla and produces lichexanthone (Hu and Chen 2003). Pyxine flavicans is similar to P. australiensis Kalb regarding the absence of soredia and isidia and both species are frequently lignicolous but occasionally grow on rocks. However, P. flavicans differs from $P$. australiensis in having marginal and laminal pseudocyphellae, lichexanthone and a white medulla in the stipe (Elix 2009). Pyxine flavicans is similar to $P$. himalayensis in terms of the type of apothecia and lack of lichexanthone. However, $P$. himalayensis has a colourless internal stipe.

Selected specimens examined (KUN). CHINA: SICHUAN PROVINCE: Muli Co., 2850 m elev., on Pinus yunnanensis, 23 Aug 1983, L. S. Wang 83-1869(A); XIZANG PROVINCE: Chayu Co., along the road from Muruo Vil. to Bingzhongluo, $3833 \mathrm{~m}$ elev., $28^{\circ} 35.781^{\prime} \mathrm{N}, 98^{\circ} 06.404^{\prime} \mathrm{E}$, on Pinus armandii, 26 Sep 2014, L. S. Wang et al. 14-46763; YUNNAN PROVINCE: Jianchuan Co., Shibao Mt., 2620 m elev., $26^{\circ} 22.920^{\prime} \mathrm{N}, 99^{\circ} 49.811^{\prime} \mathrm{E}$, on bark, 24 Jun 2014, L. S. Wang et al. 14-43995; Nujiang Co., Chide Vil., 1916 m elev., 27² $22^{\prime} 32.40^{\prime \prime N}$, 98 $43^{\prime} 18.59^{\prime \prime E}$, on Juglans, 4 Aug 2015, L. S. Wang et al. 15-48196. 


\section{Pyxine hengduanensis M. X. Yang \& Li S. Wang, sp. nov.}

MycoBank No.: MB819957

Figure 3

Holotype. CHINA, YUNNAN PROVINCE, Nujiang Pref., Dizhengdang Vil., 1858 m elevation, $28^{\circ} 05^{\prime} 00.86^{\prime \prime N}$, 98¹9'39.97"E, on bark, 2 Aug 2015, L. S. Wang et al. KUN-L 15-48082. GenBank accession No.: ITS $=$ KY611889, mtSSU $=$ KY751396.

Description. Thallus corticolous, $4-9 \mathrm{~cm}$ wide, firmly to loosely adnate to substrate. Lobes linear, compact, imbricate to discrete, (0.5) 1-2.5 mm wide, upper cortex plane but often slightly concave towards the tips; pseudocyphellae linear, marginal; upper surface grey to greyish-green, lower-side black; rhizines dense, squarrosely branched. Soralia marginal, labriform; soredia grey to bluish-grey, powdery to granular. Medulla pale yellow. Dactyls and isidia absent. Apothecia absent. Upper cortex K+ yellowish, UV-; medulla K-, C-; containing chloroatranorin (minor) and unknown terpenes.

Habitat and distribution. Growing on bark of Quercus and Alnus spp. Range $1700-3060 \mathrm{~m}$ elevation in semi-arid environments; known only from Yunnan, Sichuan and Xizang in China.

Etymology. The epithet hengduanensis refers to the type locality of the species, the Hengduan Mountains region.

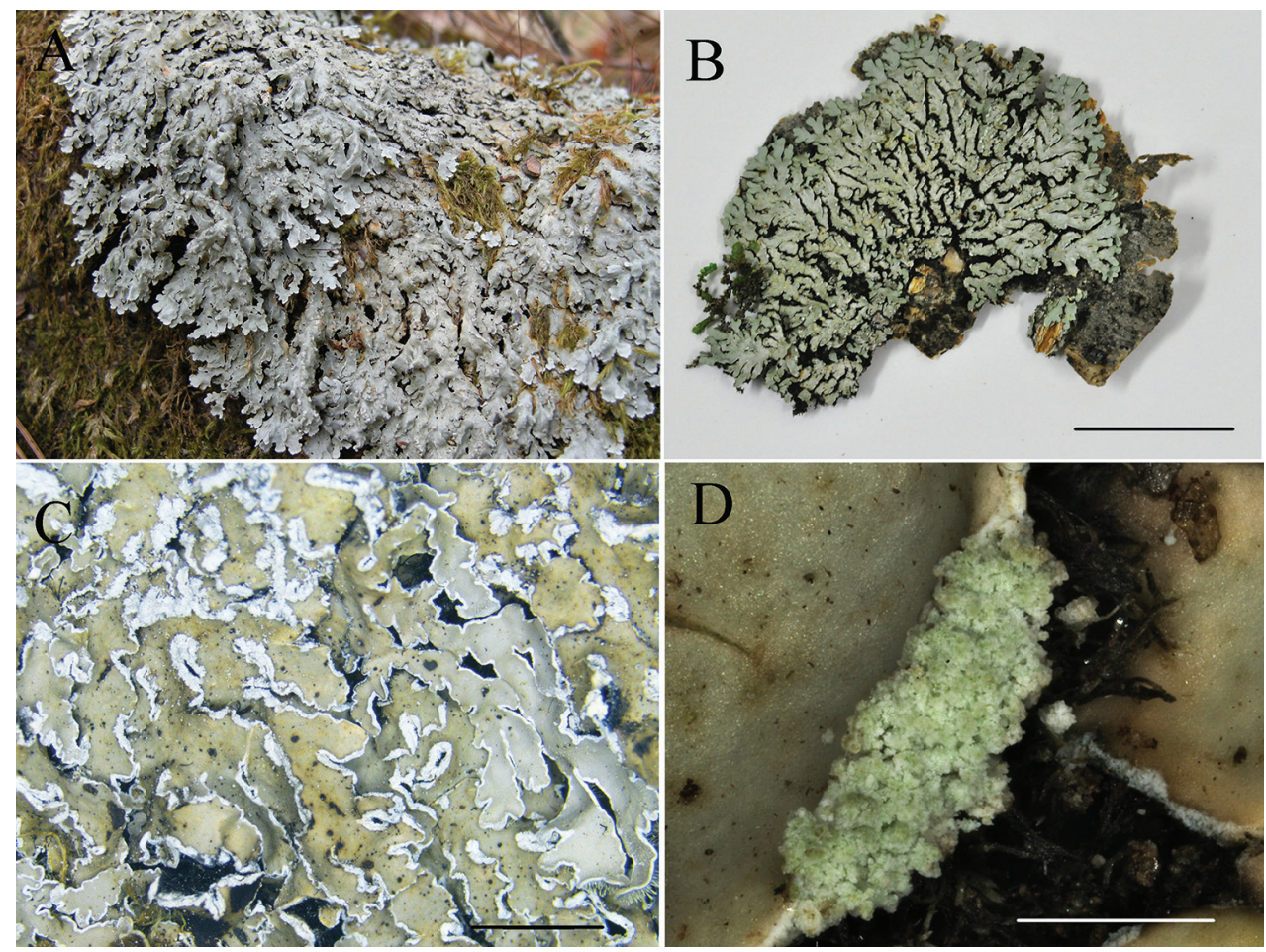

Figure 3. Pyxine hengduanensis: A (KUN-L 09-30247) photographed by Li-Song Wang, in situ at the type locality B-D (KUN-L 15-48082), photographed by Mei-xia Yang B Thallus C upper surface of thallus D marginal labriform soralia. Scale bars: $2 \mathrm{~cm}(\mathbf{B}) ; 5 \mathrm{~mm}(\mathbf{C}) ; 0.5 \mathrm{~mm}$ (D). 
Notes. Pyxine hengduanensis is characterised by a corticolous habit, yellowish-grey to greyish-green thallus, marginal labriform soralia, pale yellow medulla and the absence of atranorin. Pyxine hengduanensis is most closely related to $P$. sorediata, as inferred from the phylogenetic tree (Fig. 1); P. sorediata is also corticolous but has a yellow or yellow-orange medulla and soralia that develop marginally from fissures and then become laminal and orbicular (Elix 2009), while P. hengduanensis has marginal labriform soralia developing from the centre of the pseudocyphellae, grey to bluishgrey soredia and a pale yellow medulla. Pyxine hengduanensis also resembles $P$. retirugella Nyl. (Elix 2009) in the marginal and laminal pseudocyphellae, but it differs in having white or creamy and $\mathrm{K}+$ yellow turning red medulla and norstictic acid as the main compound (Mongkolsuk et al. 2012).

Selected specimens examined (KUN). CHINA: SICHUAN PROVINCE: Dukou Co., Yanbian Vil., Shibao Mt., 2900 m elev., 29 Jun 1983, L. S. Wang 83-635; Nanping Co., Jiuzhaigou, 2000 m elev., on Pinus, 23 Sep 1986, L. S. Wang 86-2591. XIZANG PROVINCE: Linzhi Co., 3060 m elev., 2950'249"N, 94\%44'728"E, on Quercus spp. 20 Aug 2007, L. S. Wang et al. 07-28389; YUNNAN PROVINCE: Luquan Co., 30 $\mathrm{km}$ from Sapanying Co. to Zehei Co., $2540 \mathrm{~m}$ elev., 2604'24.53"N, 102³6'19.15"E, on moss, 19 Apr 2014, L. S. Wang et al. 14-43258; Lufeng Co., Heijin Vil., $1800 \mathrm{~m}$ elev., 2520'146"N, $102^{\circ} 05^{\prime} 835^{\prime} \mathrm{E}$, on bark, 1 May 2009, L. S. Wang 09-30247.

\section{Pyxine yunnanensis M. X. Yang \& Li S. Wang, sp. nov.}

MycoBank No.: MB819958

Figure 4

Holotype. CHINA, YUNNAN PROVINCE, Yongren Co., Lagu Vil., 1050 m elevation, $26^{\circ} 23.239^{\prime} \mathrm{N}, 101^{\circ} 25.120^{\prime} \mathrm{E}$, on rock, 4 Dec 2013, L. S. Wang et al. KUN-L 1341372. GenBank accession No.: ITS = KY611870, mtSSU = KY751377.

Description. Thallus saxicolous, up to $7 \mathrm{~cm}$ in diam., closely appressed to the substrate. Lobes radiating, irregularly branched, plane to slightly concave, $0.2-1.0 \mathrm{~mm}$ wide, subround to truncate at the apices. Upper surface pale grey to yellowish-grey, sparsely pruinose at the lobe tips or epruinose. Lower surface brownish-black, rarely pale brown, rhizines indistinct, sparse to moderately abundant, brownish-black to black. Isidia and soredia absent. Medulla pale yellow in the upper part, white in the lower part. Apothecia abundant, $0.2-0.8 \mathrm{~mm}$ wide, constricted at base, plane to possibly convex; margin black. Hymenium height $80-120 \mu \mathrm{m}$; hypothecium light brown to brown, internal stipe white; spore brown with two cells, 10-15 $\times 4-7 \mu \mathrm{m}$. Upper cortex $\mathrm{K}+$ yellowish, UV+ yellow; medulla $\mathrm{K}-$, C-; containing lichexanthone, chloroatranorin (minor), zeorin and unknown terpenes (detected by TLC).

Habitat and distribution. Growing on rocks around 1050-1650 m elevation in secondary forests in a dry to semi-arid environment; known only from Yunnan.

Etymology. The epithet yunnanensis refers to the province of the type locality of the species. 

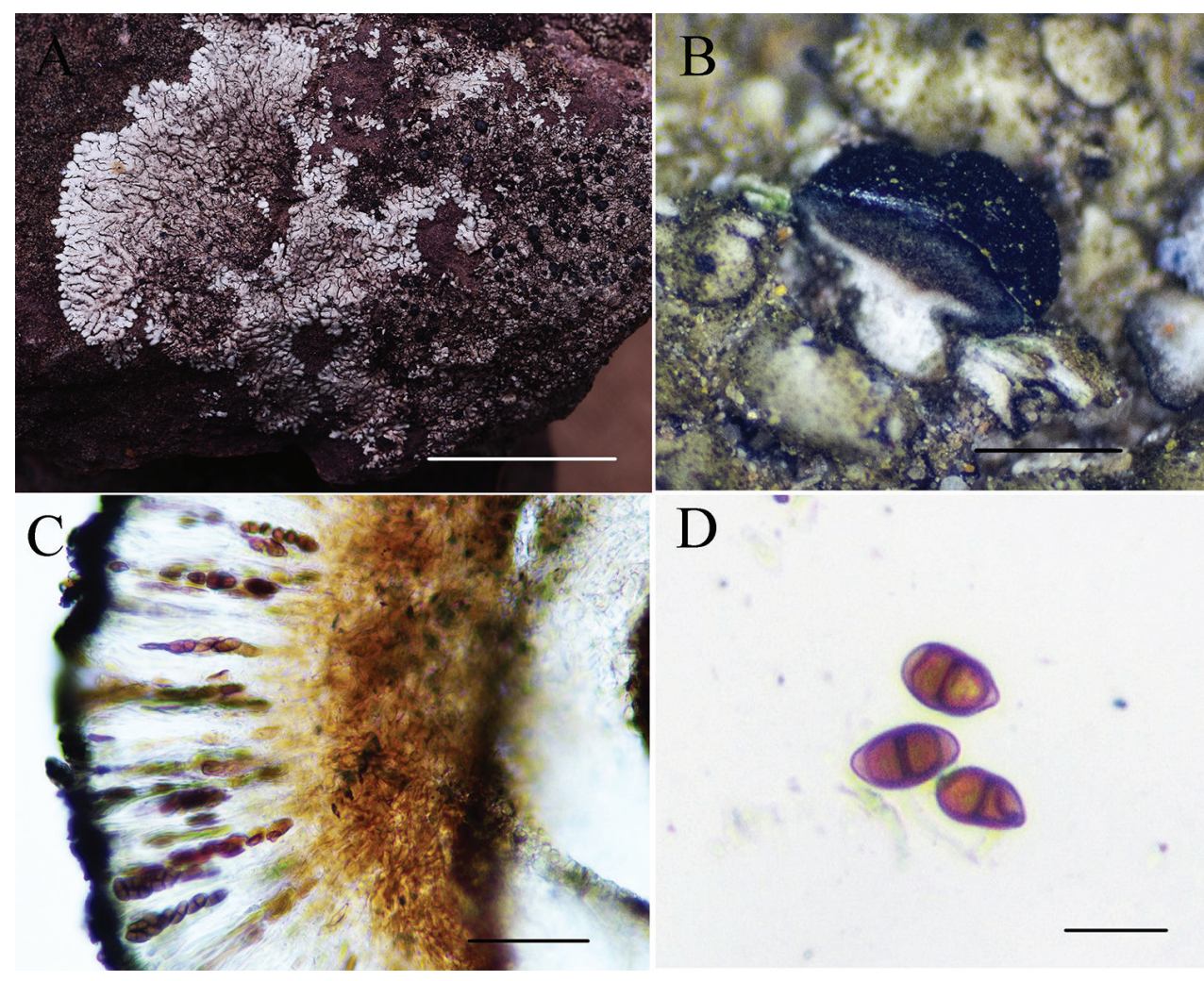

$\mathrm{D}$

Figure 4. Pyxine yunnanensis: A (KUN-L 09-30247) photographed by Li-Song Wang, in situ at the type locality B-D (KUN-L 13-41372) photographed by Mei-xia Yang B white internal stipe of apothecia C hymenium D ascospores from GAW (glycerine:alcohol:water=1:1:1). Scale bars: $1 \mathrm{~cm}(\mathbf{A}) ; 1 \mathrm{~mm}(\mathbf{B})$; $50 \mu \mathrm{m}(\mathbf{C}) ; 10 \mu \mathrm{m}(\mathbf{D})$.

Notes. Pyxine yunnanensis is characterised by small and saxicolous thalli, rather small narrow apothecia (up to $0.8 \mathrm{~mm}$ in diam.), a white internal stipe and the presence of lichexanthone. Pyxine minuta Vain. (up to $3 \mathrm{~cm}$ in diam.) resembles $P$. yunnanensis (up to $7 \mathrm{~cm}$ in diam.) in its small thalli and the presence of lichexanthone, but differs in that its internal stipe is absent or indistinct and it has a white medulla (Awasthi 1982). Pyxine pyxinoides (Müll. Arg.) Kalb and P. elixii Kalb also grow on rocks, but $P$. pyxinoides differs from $P$. yunnanensis in that it has a white medulla, an indistinct internal stipe of the apothecia and smaller ascospores $(10-15 \times 4-7 \mu \mathrm{m})$ than those of $P$. pyxinoides $(10-16 \times 4.5-8.0 \mu \mathrm{m})$. Pyxine elixii can be distinguished by its orange medulla and lack of lichexanthone (Elix 2009).

Pyxine yunnanensis is closely related to $P$. berteriana in that they have a similar type and size of apothecia and lichexanthone is present, but Pyxine berteriana differs in that it occurs in incorticolous habitat and has a yellow medulla and a yellow medulla of the stipe.

Selected specimens examined (KUN). CHINA: YUNNAN PROVNCE: Yongsheng Co., Dongjiang of Renhe Town, 1130 m elev., $26^{\circ} 20.448^{\prime} \mathrm{N}, 101^{\circ} 06.908^{\prime} \mathrm{E}$, 
on rock, 7 Dec 2013, L. S. Wang et al. 13-41413; Shawan Village of Renhe Town, 1160 m elev., 26²19.449'N, 101 05.200'E, 7 Dec 2013, L. S. Wang et al. 13-40643, 13-40694, 13-40686, 13-40641, 13-40684; Lijiang City, east of Jinan Bridge, $1310 \mathrm{~m}$ elev., $26^{\circ} 47.725^{\prime} \mathrm{N}, 100^{\circ} 25.640^{\prime} \mathrm{E}$, on rock, 8 Dec 2013, L. S. Wang et al. 13-40596.

\section{New records}

\section{Pyxine cognata Stirt}

= Pyxine berteriana var. himalaica D.D. Awasthi

Description. Upper surface white to whitish-grey or grey-brown; isidia and soredia absent; medulla orange-yellow to orange; lower surface black in the centre, paler towards the margin; apothecia common, (0.3) 0.5-1.0 (1.5) mm wide; internal stipe upper part orange, $\mathrm{K}+$ purple, $\mathrm{P}-$; lower part yellow or much paler than upper part, $\mathrm{K}-, \mathrm{P}-$. Upper cortex $\mathrm{K}-$, UV+ yellow, medulla $\mathrm{K}-$ or $\mathrm{K}+$ pale red, $\mathrm{C}-, \mathrm{P}-$ or $\mathrm{P}+$ orange; containing lichexanthone (major), triterpenes, unknown pigment (minor) (detected by TLC).

Habitat and distribution. Growing on bark of Quercus and Juglans spp. Range 1090-2230 m elevation in semi-arid environments. Worldwide distribution: India (Awasthi 1982), Brazil (Aptroot 2014), Thailand (Mongkolsuk et al. 2012) and Australia (Elix 2009); newly recorded in China.

Notes. Pyxine berteriana var. himalaica was described by Awasthi (1982) as a variety based on the pale yellow to yellow medulla and a narrow distribution from the Himalayan region and central India. Pyxine cognata is very similar to P. berteriana var. himalaica in the presence of lichexanthone, the pigmented medulla and the lack of isidia and soredia. However, Pyxine cognata is distinguished by a faint pruina on the lobe tips, deep yellow to rust coloured medulla and slightly larger spores, as well as for being widely distributed in tropical regions. Therefore, the morphological and ecological differences between these two species are minor. In this study, we collected specimens of both species and found that they have a similar ecology and distribution pattern. Phylogenetic analysis inferred that Pyxine berteriana var. himalaica is clustered with $P$. cognata with a high support value $(\mathrm{MLBS}=100 \%, \mathrm{PP}=1.00)$. Based on the combination of molecular, morphological and ecological information, we propose $P$. berteriana var. himalaica as a synonym for $P$. cognata.

Pyxine cognata is most similar to $P$. berteriana in that it contains lichexanthone, lacks isidia and soredia and has a pigmented medulla; however, P. cognata can be distinguished by the presence of lichexanthone in the cortex, an orange medulla and an orange-yellow internal stipe of apothecia with $\mathrm{K}+$ purple. In comparison, $P$. berteriana has a pale yellow to yellow medulla and the internal stipe is pale yellow to yellow. (Kalb 1987). Despite the broad similarities, these species are not closely related; $P$. cognata seems to share a unique ancestor with $P$. subcinerea. Pyxine subcinerea differs in that it has marginal soralia and obscurascens-type apothecia (Elix 2009). (Fig. 1). 
Selected specimens examined (KUN). CHINA: SICHUAN PROVINCE: Miyi Co., Malong north slope, 2100 m elev., on Carya spp., 5 Jul 1983, L. S. Wang 83-698; Dukou Co., Dabaoding, 1900 m elev., 21 Jun 1983, L. S. Wang 83-212. YUNNAN PROVINCE: Yuanmou Co. Langbapu Forest Soil, 1612 m elev., 2541'01.76"N, 10141'25.78"E, on branch, 21 Apr 2014, c14-43569, 14-43539; Yongren Co., from Menghu to Wanma, 1543 m elev., 26³' $15.15^{\prime \prime N}, 1^{\circ} 25^{\prime} 56.86^{\prime E}, 3$ Dec 2013, L. S. Wang et al. 13-40767.

\section{Pyxine himalayensis Awas}

Description. Thallus grey-white, soredia and isidia absent; medulla yellow to orangeyellow; apothecia common, laminal, constricted at base, up to $2 \mathrm{~mm}$ in diam.; internal stipe colourless, $\mathrm{K}-$, hypothecium 50-80 $\mu \mathrm{m}$ thick, spores brown, 15-25 × 6-9 $\mu \mathrm{m}$. Upper cortex $\mathrm{K}+$ yellow, UV-, medulla $\mathrm{K}-, \mathrm{C}-, \mathrm{P}-$; containing atranorin (major), $+/$ - zeroin, triterpense.

Habitat and distribution. Growing on bark of Rhododendron, Quercus, Alnus, Juglans, Sophora, Lonicera and Lyonia spp. and rarely on rocks, at elevations of 1330$3600 \mathrm{~m}$ in semi-arid environments. Worldwide distribution: India (Awasthi 1982) and added here to the flora of China.

Notes. Pyxine himalayensis is distinctive for having lobes $1.5-3.0 \mathrm{~mm}$ wide, an orange medulla and a lack of isidia and soredia, lichexanthone and norstictic acid. Pyxine himalayensis was first described by Awasthi (1982) and it is characterised by an orange medulla and colourless internal stipe of apothecia. The closely related Pyxine limbulata is described as having a yellow medulla and a brown internal stipe (Hu and Chen 2003). There are 24 specimens of this species in the KUN-L. The phylogenetic analysis of ITS and mtSSU sequences confirm that these are independent species.

Selected specimens examined (KUN). CHINA: SICHUAN PROVINCE: Dukou City, Shibao Mt., 2800 m elev., 29 Jun 1983, L. S. Wang 83-628; Yuanyang Co., Bailing commune, 3100 m elev., on Quercus, 11 Aug 1983, L. S. Wang 83-1508; $3250 \mathrm{~m}$ elev., on stone, 10 Aug 1983, L. S. Wang 83-1483; Muli Co., Yazui forest farm, on Quercus, 3000 m elev., 20 Aug 1983, L. S. Wang 83-1589, 83-1596; Donglang, 3000 m elev., on bark, 10 Sep 1983, L. S. Wang 83-2220. XIZANG PROVINCE: Bomi Co., Gang vil., 2688 m elev., 29 $52.983^{\prime} \mathrm{N}, 095^{\circ} 33.593^{\prime} \mathrm{E}$, on branch of Populus yunnanensis, 20 Sep 2014, L. $S$. Wang et al. 14-46203, 14-46162. YUNNAN PROVINCE: Luquan Co., $30 \mathrm{~km}$ from Sapanying Co. to Zehei Co., 2540 m elev., 2604'24.53"N, 102³6'19.15"E, on Quercus, 19 Apr 2014, L. S. Wang et al. 14-43218, 14-43204; Luquan Co., Zhongcun Vil., $2350 \mathrm{~m}$ elev., 2520'146"N, 10205'835"E, on bark of Quercus, 1 May 2009, L. S. Wang 09-30279.

\section{Pyxine minuta Vain}

Description. Pyxine minuta is characterised by narrow lobes, centrally subcrustaceous, saxicolous thalli, a whitish-grey or grey-brown upper surface; brownish-black lower 
surface with black and simple rhizines, a lack of isidia and soredia and a white or whitish stramineous medulla. Apothecia common, $0.5-1.5 \mathrm{~mm}$ wide; internal stipe absent or not distinct. Upper cortex $\mathrm{K}+$ yellowish, $\mathrm{UV}+$ yellow, medulla $\mathrm{K}-$, $\mathrm{C}$-; containing lichexanthone (major) and terpenoids (detected by TLC).

Habitat and distribution. Growing on bark of Quercus spp. or rock around 1090$2230 \mathrm{~m}$ elevation in semi-arid environments. Worldwide distribution: India (Awasthi 1982), Australia (Rogers 1986) and newly recorded in China.

Notes. There is some confusion in the classification of Pyxine minuta and P. pyxinoides. Pyxine minuta is characterised by narrow lobes, an absent or indistinct internal stipe, small spores $(11-16(18) \times 5-7 \mu \mathrm{m})$ and a white medulla. Based on the world key to Pyxine species with lichexanthone (Aptroot et al. 2014; Kalb 1987; Huneck et al. 1987), the characteristics of Pyxine pyxinoides are: Thallus without isidia, pustules or soredia, usually with apothecia; Medulla yellow, ochraceous or salmon; apothecium margin black, not thalline; apothecium without a clear stipe; one TLC run of a portion of the thallus without apothecia showed traces of a substance running like norstictic acid (Obermayer and Kalb 2010); neotropical. We did not find any specimens of $P$. pyxinoides in our collections.

Selected specimens examined (KUN). CHINA: SICHUAN PROVINCE: Dukou Co., Dabaoding, 1950 m elev., 21 Jun 1983, L. S. Wang 83-206. YUNNAN PROVINCE: Yongsheng Co., Shawan village of Renhe town, $1160 \mathrm{~m}$ elev., $26^{\circ} 19.449^{\prime} \mathrm{N}, 101^{\circ} 05.200^{\prime} \mathrm{E}$, on rock, 7 Dec 2013, L. S. Wang et al. 13-40630, 1340695; Yongren Co., Lagu village, $1050 \mathrm{~m}$ elev., 26²3.239'N, 101²5.120'E, on rock, 4 Dec 2013, L. S. Wang et al. 13-41380; Jinggu Co., on the way to Zhenyuan, $1800 \mathrm{~m}$ elev., 21 Aug 1994, L. S. Wang et al. 94-14247.

\section{Key to the species of the genus Pyxine in China}

Thallus UV+, lichexanthone present 2

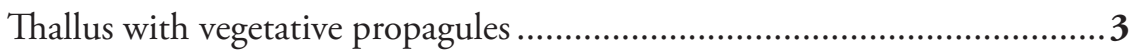

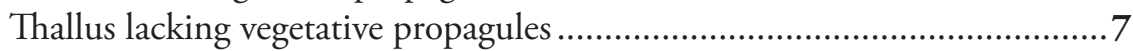

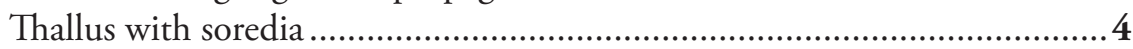

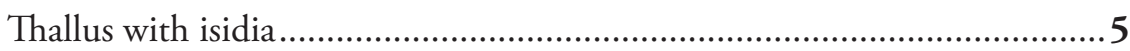

Medulla yellow

P. subcinerea

Medulla white. P. cocoes

Medulla yellow; isidia dactyliform .P. endochrysina

Medulla white; isidia cylindrical. . .6

Norstictic acid present P. consocians

Norstictic acid absent. P. coralligera Atranorin present. P. cognata Atranorin absent 8 Medulla pale yellow to yellow Medulla white. P. berteriana 
$9 \quad$ Internal stipe of apothecia absent or indistinct.....................................10

- Internal stipe of apothecia well developed ..............................................11

$10 \quad$ Norstictic acid present, as well as other triterpenes.................. P. microspora Norstictic acid absent................................................................ P. minuta

11 Internal stipe of apothecia brown, $\mathrm{K}+$ red violet.......................... P. petricola Internal stipe of apothecia white, $\mathrm{K}-\ldots \ldots \ldots \ldots \ldots \ldots \ldots \ldots \ldots \ldots \ldots \ldots \ldots . . .1$ P. yunnanensis

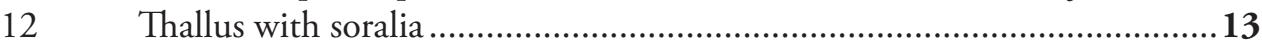

Thallus lacking vegetative propagules .......................................................16

13 Medulla white, soralia laminal; norstictic acid present.............. P. copelandii

Medulla yellow; soralia marginal; norstictic acid absent ...........................14

14 Atranorin absent; soralia labriform..................................... hengduanensis

Atranorin present; soralia granular, laminal or orbicular.............................15

15 Lobe margin without pseudocyphellae; soredia yellow ............P. meissnerina Lobe margin with intermittent pseudocyphellae; soredia grey to bluish-grey.

P. sorediata

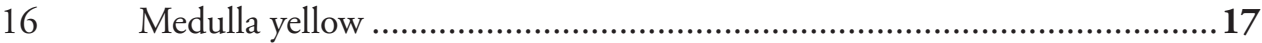

- Medulla white........................................................................ P. philippina

17 Internal stipe of apothecia colourless.................................. P. himalayensis

- Internal stipe of apothecia brown or yellow...............................................18

18 Internal stipe brown, $\mathrm{K}+$ red violet........................................... P. limbulata

Internal stipe of apothecia pale yellow; upper medulla yellow, lower medulla white

P. flavicans

\section{Acknowledgements}

The authors are grateful to Dr. Melissa Dawes for the scientific editing, as well as Prof. Bernard Goffinet from the University of Connecticut and Prof. James R. Shevock from the California Academy of Sciences for guidance and help with writing in English. Sincere thanks are extended to Institute of Microbiology, Chinese Academy of Sciences for the loan of specimens. This study was supported by grants from the National Natural Science Foundation of China (No. 31370069, 31400022, 31670028, 31750001), the Second Tibetan Plateau Scientific Expedition and the China Scholarship Council.

\section{References}

Amtoft A (2002) Pyxine subcinerea in the Eastern United States. Bryologist 105: 270-272. https://doi.org/10.1639/0007-2745(2002)105[0270:PSITEU]2.0.CO;2

Aptroot A, Jungbluth P, Cáceres M (2014) A world key to the species of Pyxine with lichexanthone, with a new species from Brazil. Lichenologist 46: 669-672. https://doi.org/10.1017/ S0024282914000231

Awasthi DD (1982) Pyxine in India. Phytomorphology 30: 359-379. 
Cáceres MES, Lücking R, Rambold G (2007) Phorophyte specificity and environmental parameters versus stochasticity as determinants for species composition of corticolous lichen communities in the Atlantic rain forest of northeastern Brazil. Mycological Progress 6: 117-136. https://doi.org/10.1007/s11557-007-0532-2

Cáceres MES, Lücking R, Rambold G (2008) Corticolous microlichens in northeastern Brazil: habitat differentiation between coastal Mata Atlântica, Caatinga and Brejos de Altitude. Bryologist 111: 98-117. https://doi.org/10.1639/0007-2745(2008)111[98:CMIN $\mathrm{BH}] 2.0 . \mathrm{CO} ; 2$

Crespo A, Blanco O, Llimona X, Hawksworth DL (2004) Coscinocladium, an overlooked endemic and monotypic mediterranean lichen genus of Physciaceae, reinstated by molecular phylogenetic analysis. Taxon 53: 405-414. https://doi.org/10.2307/4135618

Elix JA (2009) Physciacae, 3. Pyxine. In: McCarthy PM (Ed.) Flora of Australia Volume 57. Lchens 5, ABRS \& CSIRO Publishing, Canberra \& Melbourne, 517-533.

Gaya E, Högnabba F, Holguin A, Molnar K, Fernández-Brime S, Stenroos S, Arup U, Søchting U, den Boom PV, Lücking R, Sipman HJM, Lutzoni F (2012) Implementing a cumulative supermatrix approach for a comprehensive phylogenetic study of the Teloschistales (Pezizomycotina, Ascomycota). Molecular Phylogenetics and Evolution 63: 374-387. https:// doi.org/10.1016/j.ympev.2012.01.012

Gardes M, Bruns TD (1993) ITS primers with enhanced specificity for basidiomycetes application to the identification of mycorrhizae and rusts. Molecular Ecology 2: 113-118. https:// doi.org/10.1111/j.1365-294X.1993.tb00005.x

Hu GR, Chen JB (2003) The lichen family Physciaceae (Ascomycota) in China VI. The genus Pyxine. Mycotaxon 86: 445-454.

Huelsenbeck JP, Ronquist F (2001) MRBAYES: Bayesian inference of phylogenetic trees. Bioinformatics 17: 754-755. https://doi.org/10.1093/bioinformatics/17.8.754

Huneck S, Morales MA, Kalb K (1987) The chemistry of Dirinaria and Pyxine species (Pyxinaceae) from South America. Journal of the Hattori Botanical Laboratory 62: 331-338.

Imshaug HA (1957) The lichen genus Pyxine in North and Middle America. Transactions of the American Microscopical Society 56: 246-269.

Jungbluth P, Marcelli MP (2011) The Pyxine pungens complex in Sao Paulo state, Brazil. Bryologist 114: 166-177. https://doi.org/10.1639/0007-2745-114.1.166

Kalb K (1987) Brasilianische Flechten, 1. Die Gattung Pyxine. Berlin-Stuttgart, J. CRAMER, $5-82$.

Kalb K (2004) New or otherwise interesting lichens II. Bibliotheca Lichenologica 88: 301-329.

Kashiwadani H (1977a) On the Japanese species of the genus Pyxine (Lichens) (1). Journal of Japanese Botany 52(5): 137-144.

Kashiwadani H (1977b) On the Japanese species of the genus Pyxine (Lichens) (2). Journal of Japanese Botany 52(6): 161-168.

Kashiwadani H (1977) The genus Pyxine (Lichen) in Papua New Guinea. Bull. Natl. Sci. Mus. ser. B (Botany) 3: 63-70.

Katoh K, Kuma K, Toh H, Miyata T (2005) MAFFT version 5: improvement in accuracy of multiple sequence alignment. Nucleic Acids Research 33: 511-518. https://doi. org/10.1093/nar/gki198 
McCarthy PM, Kantvilas G, Louwhoff SHJJ (2001) Lichenological Contributions in Honour of Jack Elix. Bibliotheca Lichenologica 78: 141-167.

Moberg R (1983) Studies on Physciaceae (Lichen) II. The genus Pyxine in Europe. Lichenologist 15(2): 161-167. https://doi.org/10.1017/S0024282983000250

Mongkolsuk P, Meesim S, Poengsungnoen V, Kalb K (2012) The lichen family Physciaceae in Thailand - I. The genus Pyxine. Phytotaxa 59: 32-54. https://doi.org/10.11646/phytotaxa.59.1.2

Nayaka S, Upreti DK, Ponmurugan P, Ayyappadasan G (2013) Two new species of saxicolous Pyxine with yellow medulla from southern India. Lichenologist 45: 3-8. https://doi. org/10.1017/S0024282912000618

Nylander JAA (2005) Mrmodeltest v. 2.3. Uppsala: Computer program distributed by the author.

Obermayer W, Kalb K (2010). Notes on three species of Pyxine (Lichenized Ascomycetes) from Tibet and adjacent regions. Bibliotheca Licheologica 104: 247-267.

Orange A, James PW, White FJ (2001) Microchemical Methods for the Identification of Lichen. $2^{\text {nd }}$ ed. British Lichen Society, London, 1-101.

Posada D (2008) jModelTest: phylogenetic model averaging. Molecular Biology and Evolution 25: 1253-1256. https://doi.org/10.1093/molbev/msn083

Prieto M, Wedin M (2017) Phylogeny, taxonomy and diversification events in the Caliciaceae. Fungal Diversity 82: 221-238. https://doi.org/10.1007/s13225-016-0372-y

Rambaut A, Drummond AJ (2003) Tracer v1.6. Available from website http://tree.bio.ed.ac. uk/software/tracer/

Rambaut A (2012) FigTree: Tree figure drawing tool, v.1.4.0. Institute of Evolutionary Biology, University of Edinburgh. http://tree.bio.ed.ac.uk/software/figtree/

Rogers RW (1986) The genus Pyxine (Physciaceae, lichenized ascomycetes) in Australia. Australia Journal of Boany 34: 131-154. https://doi.org/10.1071/BT9860131

Schmull M, Miadlikowska J, Pelzer M, Stocker-Wörgötter E, Hofstetter V, Fraker E, et al. (2011) Phylogenetic affiliations of members of the heterogeneous lichen-forming fungi of the genus Lecidea Sensu Zahlbruckner (lecanoromycetes, ascomycota). Mycologia 103(5): 983-1003. https://doi.org/10.3852/10-234

Stamatakis A (2006) RAxML-VI-HPC: maximum likelihood-based phylogenetic analyses with thousands of taxa and mixed models. Bioinformatics 22: 2688-2690. https://doi. org/10.1093/bioinformatics/btl446

Shukla V, Upreti DK (2008) Effect of metallic pollutants on the physiology of lichen, Pyxine subcinerea stirton in Garhwal Himalayas. Environmental Monitoring \& Assessment 141: 237-243. https://doi.org/10.1007/s10661-007-9891-z

Swofford DL (2003) PAUP*. Phylogenetic Analysis Using Parsimony (*and Other Methods). Sunderland, Massachusetts: Sinauer Associates.

Swinscow TDV , Krog H (1975) The genus Pyxine in the East Africa. Norwegian Journal of Botany 22: 43-68.

Wedin M, Tibell L (1997) Phylogeny and evolution of Caliciaceae, Mycocaliciaceae and Sphinctrinaceae (Ascomycota), with notes on the evolution of the prototunicate ascus. Canadian Journal of Botany 75: 1236-1242. https://doi.org/10.1139/b97-837 
Wedin M, Grube M (2002) Parsimony analyses of mtSSU and nIT rDNA sequences reveal the natural relationships of the lichen families Physciaceae and Caliciaceae. Taxon 51: 655660. https://doi.org/10.2307/1555020

Wei JC (1991) An enumeration of lichens in China. International Academic publishers, Beijing, 216-218.

Wei XL, Hur JS (2007) Foliose genera of Physciaceae (lichenized Ascomycota) of South Korea. Mycotaxon 102: 127-137.

White TJ, Bruns TD, Lee S, Taylor JW (1990) Amplification and direct sequencing of fungal ribosomal genes for phylogenetics. In: Innis MA, Gelfand DH, Sninsky JJ, White TJ (Eds) PCR Protocols. Academic Press, San Diego, 315-322.

Zoller S, Scheidegger C, Sperisen C (1999) PCR primers for the amplification of mitochondrial small submit ribosomal DNA of lichen-forming ascomycetes. Lichenologist 31(5): 511-516. https://doi.org/10.1006/lich.1999.0220 